Georgia State University

ScholarWorks @ Georgia State University

Philosophy Theses

Department of Philosophy

Spring 5-7-2011

\title{
Rescuing Inclusive Legal Positivism from the Charge of Inconsistency
}

Cindy L. Phillips

Georgia State University

Follow this and additional works at: https://scholarworks.gsu.edu/philosophy_theses

Part of the Philosophy Commons

\section{Recommended Citation}

Phillips, Cindy L., "Rescuing Inclusive Legal Positivism from the Charge of Inconsistency." Thesis, Georgia State University, 2011.

doi: https://doi.org/10.57709/1947712

This Thesis is brought to you for free and open access by the Department of Philosophy at ScholarWorks @ Georgia State University. It has been accepted for inclusion in Philosophy Theses by an authorized administrator of ScholarWorks @ Georgia State University. For more information, please contact scholarworks@gsu.edu. 


\title{
RESCUING HART AND INCLUSIVE LEGAL POSITIVISM FROM THE CHARGE OF INCONSISTENCY
}

by

CINDY L. PHILLIPS

Under the Direction of William Edmundson and Christie Hartley

\begin{abstract}
Scott Shapiro, an exclusive legal positivist, argues that inclusive legal positivism is inconsistent with the claim that legal norms provide reasons for officials and citizens to act in specified ways. I defend inclusive legal positivism from Shapiro's charge of inconsistency.
\end{abstract}

INDEX WORDS: $\quad$ Practical Difference Thesis, Exclusive legal positivism, Inclusive legal positivism, Conventionality Thesis, Scott Shapiro, Contentindependent reasons, Peremptory reasons 
RESCUING HART AND INCLUSIVE LEGAL POSITIVISM FROM THE CHARGE OF INCONSISTENCY

by

CINDY L. PHILLIPS

A Thesis Submitted in Partial Fulfillment of the Requirements for the Degree of

Master of Arts

in the College of Arts and Sciences

Georgia State University

2011 
Copyright by

Cindy Laurie Phillips

2011 


\section{RESCUING HART AND INCLUSIVE LEGAL POSITIVSM FROM THE CHARGE OF INCONSISTENCY}

by

CINDY L. PHILLIPS

Committee Chair: William Edmundson

Christie Hartley

Committee: Andrew Altman

Kenneth Ehrenberg

George Rainbolt

Electronic Version Approved:

Office of Graduate Studies

College of Arts and Sciences

Georgia State University

May 2011 


\section{ACKNOWLEDGEMENTS}

I thank Kenneth Ehrenberg for introducing me to legal philosophy and remaining in close contact as I reach each milestone. I thank Sandra Dwyer for humoring me while I talked at great lengths about anything on my mind in her office. I thank Michael Sevel for his helpful comments on an earlier draft. I thank my reading group members, Hunter Thomsen, Paul Tulipana, and Kyle Hirsch, for their support and conversations. I am grateful to all of my committee members for all of the time and energy they donated to my project during this process. Andrew Altman detected logical blunders that no one else saw on repeated drafts of my thesis and gave me the most devastating counterarguments to which to respond. George Rainbolt taught me the invaluable lesson that the presentation and clarity of my argument is just as important as the soundness of the argument itself. George also showed me how to attain clarity, which is something for which I continue to strive. William Edmundson is a legal theory pit bull. Bill not only gave me effective strategies on how to argue that I employed throughout this thesis but also took certain steps to prepare me for the profession. Bill came through for me when I needed his help throughout my time spent at GSU, for which I am very grateful. Christie Hartley is a wonderful mentor and a very effective teacher. I took two consecutive classes with Christie where she offered ample constructive criticism on four term papers in preparation for my thesis. Under her guidance, I was able to mature as a thinker and a writer, which prepared me to address more advanced content issues with the other committee members. I also thank Christie for generously scheduling thesis meetings and always having the time to help with me with projects other than my thesis. All in all, writing this thesis was an amazing learning process for me, and I see how the thesis writing process can be an incredible pedagogical tool. Thank you. 


\section{TABLE OF CONTENTS}

\section{ACKNOWLEDGMENTS iv}

1 Introduction 1

2 Overview of Shapiro's challenge 3

3 Controversy over content-independent reasons for acting 5

$4 \quad$ Peremptory reasons for acting 18

$5 \quad$ The counterfactual test 26

6 Conclusion 33

WORKS CITED 34 


\section{Introduction}

Legal positivism is the view that law has a fundamentally social nature. Legal positivists believe that law is a socially constructed human artifact that is the outcome of social processes such as winning the majority vote in the legislative branch. More specifically, the core commitment of legal positivism is the "Social Fact Thesis," which is the thesis that the existence of legal systems and legal rules is ultimately determined by certain facts about social groups.

One could ask if it is conceptually possible to include moral properties in the criteria of legality. For example, does the Due Process Clause specify a constitutional test of fairness requiring consistency with fairness to be one of the criteria for legal validity? Exclusive legal positivists answer in the negative; they claim it is conceptually impossible for there to be a legal system that includes moral criteria in the rule that determines which rules are legally valid. The rule that determines which rules are legally valid is known as the "rule of recognition." They say that the United States' rule of recognition cannot specify fairness as a condition of legal validity. $^{2}$ Inclusive legal positivists, however, claim it is conceptually possible for there to be at least one legal system that includes moral criteria in the rule of recognition. They say that the United States' rule of recognition can specify fairness as a condition of legal validity via the Due Process Clause.

One might ask whether inclusive legal positivism is compatible with the Social Fact Thesis. Jules Coleman argues that inclusive legal positivism and the Social Fact Thesis are compatible. ${ }^{3}$ The Social Fact Thesis, he claims, is consistent with the possibility that moral rules

\footnotetext{
${ }^{1}$ See H.L.A. Hart The Concept of Law, $2^{\text {nd }}$ ed. (Oxford, Clarendon Press, 1994). The "rule of recognition" is the rule that determines which rules should enjoy membership in the category "law."

${ }^{2}$ For the exclusive legal positivist answer, see Joseph Raz, "The Inner Logic of the Law" in Ethics in the Public Domain: Essays in the Morality of Law and Politics, rev. ed. (Oxford Clarendon Press, 1996), 242.

${ }^{3}$ See Jules Coleman, "Incorporationism, Conventionality, and the Practical Difference Thesis," in Hart's Postscripts (hereafter called "Incorporationism").
} 
can be legal rules as long as the ultimate validity of the moral rule stems from a conventional rule - that is, the rule of recognition. Coleman's view, therefore, includes the "Conventionality Thesis," which is the thesis that every legal system contains a conventional rule that imposes a duty on courts to evaluate conduct in light of rules that bear certain characteristics. ${ }^{4}$

One leading exclusive legal positivist, Scott Shapiro, ${ }^{5}$ argues that an inclusive rule of recognition cannot validate moral rules that make a practical difference in the reasoning of agents. The Practical Difference Thesis, roughly, asserts that the law must make a difference in the reasoning of agents both conceptually and practically. One way that the law must make a practical difference is by guiding conduct and deliberation. For example, the law must be capable of informing citizens of the content of their legal duties or create a reason for citizens to follow their legal duties. Shapiro's view is that moral rules validated by an inclusive rule of recognition cannot give any such guidance. He then argues that the three theses-Inclusive Legal Positivism, the Conventionality Thesis, and the Practical Difference Thesis-form an inconsistent triad. Shapiro's challenge is that one of these three theses must be given up, and Shapiro suggests that inclusive legal positivism should be given up for exclusive legal positivism.

Inclusive legal positivists answer Shapiro's challenge in a variety of ways. ${ }^{6}$ Some say that it only matters that some legal rules are capable of making a practical difference, and it does

\footnotetext{
${ }^{4}$ Scott Shapiro, "Law, Morality, and the Guidance of Conduct," Legal Theory 6 (2000): 128. The "Conventionality Thesis" reconciles the claim that morality can be a sufficient condition of legal validity with the core legal positivist claim that law is a social fact by asserting that moral principles can be law when they are picked out by the rule of recognition, which is a conventional rule.

5 Scott Shapiro. "On Hart's Way Out" in Hart's Postscripts: Essays on the Postscripts to the Concept of Law, ed. Jules Coleman (New York: Oxford University Press, 2005), 149-191. Also see Joseph Raz. “Authority, Law, and Morality" in Ethics and the Public Domain, ed. Joseph Raz (New York: Oxford University Press, 1996), $210-237$. Raz is the founder of contemporary exclusive legal positivism.

${ }^{6}$ See Jules Coleman, "Incorporationism," and The Practice of Principle: In Defense of a Pragmatist Approach To Legal Theory (New York: Oxford University Press, 2001), 134-148. Kenneth Himma, "H.L.A. Hart and the Practical Difference Thesis," Legal Theory 6 (2000): 1-43. Matthew Kramer, "How Moral Principles Can Enter Into
} 
not matter that every legal rule is thus capable. ${ }^{7}$ However, Shapiro argues that being capable of making a practical difference is a necessary condition for the existence of every particular legal rule. What I intend to show is that moral rules are capable of making a practical difference qua legal rule even if we assume that a rule must be capable of guiding conduct in order to count as a legal rule.

\section{Overview of Shapiro's challenge}

Shapiro's main target is H.L.A. Hart. For Hart, the function of law is the guidance of conduct. ${ }^{8}$ Shapiro argues that the law guides conduct by giving either epistemic or motivational guidance. According to Shapiro, epistemic guidance means that for the agent the "rule was the source of information regarding what counts as conformity." 9 The rule yield to pedestrians at crosswalks epistemically guides Elmo when he gleans his legal duty from the rule. An agent is motivationally guided by a legal rule when an agent takes the fact that the rule regulates the conduct in question as a reason to perform that act. Elmo is motivationally guided by his legal duty to yield to pedestrians at crosswalks when the rule creates a reason for Elmo to conform. Shapiro then unpacks how the law must make a practical difference with the following three claims:

A. Primary rules must epistemically guide judges (who are at the same time guided by the rule of recognition).

B. Primary rules must motivationally guide judges (who are at the same time guided by the rule of recognition).

the Law," Legal Theory 6 (2000): 83-108; "Throwing Light on the Role of Moral Principles in the Law," Legal Theory 8 (2002): 115-143. Robin Kar "Hart's Response to Inclusive Legal Positivism," 95 Georgetown Law Review (2007). Wilfred Waluchow, “Authority and the Practical Difference Thesis," Legal Theory 6 (2000): 45-81.

${ }^{7}$ Most inclusive legal positivists respond in this manner to Shapiro's charge of inconsistency, including Jules Coleman, Matthew Kramer, Kenneth Himma, and Wilfred Waluchow. See fn 5.

${ }^{8}$ For Hart, "it is quite vain to seek any more specific purpose which law as such serves beyond providing guides to human conduct and standards of criticisms of such conduct," Hart, The Concept of Law, 249.

${ }^{9}$ Shapiro, "Law, Morality, and the Guidance of Conduct," 146. 
C. Primary rules must epistemically guide citizens (directly or indirectly).

According to Shapiro, for legal rules to have a guidance function, the legal rule must be capable of either motivational or epistemic guidance. Thus, it is necessary that legal officials be either epistemically or motivationally guided by a legal rule. But it is not necessary that citizens be motivationally guided by legal rules because it is not clear that the law must care why a citizen follows a legal rule: it only matters that the citizen follows it (e.g., perhaps she follows rules because she fears legal sanctions). Thus, it is minimally necessary that ordinary citizens be epistemically guided by a legal rule.

Shapiro then gives two sets of arguments that are straightforward reductios against inclusive legal positivism, to which I will return. In each argument, Shapiro argues that moral rules validated by an inclusive rule of recognition can neither epistemically nor motivationally guide any agent of a legal system. Thus, moral rules validated by an inclusive rule of recognition cannot be action guiding in the manner in which legal rules are supposed to be action guiding. And since legal rules must be capable of making a practical difference-namely, by providing citizens with either epistemic or motivational guidance-in order to count as legal rules, moral rules cannot be legal rules. Again, for Shapiro, if a rule is incapable of making a practical difference, then it is not a legal rule. Moreover, if a rule makes a difference in any way other than guiding conduct and deliberation, then it is not making a practical difference qua legal rule.

There are three requirements that Shapiro must establish before we can confidently conclude that moral rules cannot be legal rules. Each of the three requirements entails that moral rules cannot be action guiding in the manner which legal rules are action guiding.

R1. Moral rules cannot be content independent reasons for acting. 
R2. Moral rules cannot be intended to be peremptory reasons for acting.

R3. Moral rules cannot be dynamic in the same manner that legal rules that pass Shapiro's counterfactual test are dynamic — that is, counterfactually, L might not have been legally valid at time $t$.

I will argue that Shapiro fails to meet the requirements of his own challenge by showing that statements R1-R3 are false. I turn Shapiro's reductio back onto him with the following argument (Let "Inclusive Legal Positivism" be ILP, the "Practical Difference Thesis" be PDT, and the "Conventionality Thesis" be CT):

1. (ILP \& PDT \& CT)

2. (ILP \& PDT \& CT) only if (R1) \& (R2) \& (R3)

3. $\sim(\mathrm{R} 1)$ or $\sim(\mathrm{R} 2)$ or $\sim(\mathrm{R} 3)$

4. Therefore, (ILP \& PDT \& CT)

I will now defend the claim that moral rules are capable of guiding conduct qua legal rule.

\section{Controversy over content-independent reasons for acting}

Shapiro argues that, for Hart, legal rules are able to guide conduct because agents treat them as "content-independent" and "peremptory" reasons for acting. ${ }^{10}$ Shapiro's definition of content independent reasons is the following:

A valid rule is a "content-independent" reason for action-it gives an agent a reason to comply irrespective of whether the agent has reasons to act on its content. The fact that the rule requires that an act be done is, by itself, a reason to perform the act. ${ }^{11}$

Shapiro understands content-independent reasons (hereafter content-independentss) as reasons to act whose force is independent of the merit of their content. Thus, on Shapiro's

\footnotetext{
${ }^{10}$ Shapiro, “On Hart's Way Out," 175. I agree with Shapiro that the concepts "content-independence" and peremptoriness" are central to Hart's conception of rule-guidance.

${ }^{11}$ Shapiro, "Law, Morality, and the Guidance of Conduct," 163.
} 
reading, Bert acts on a content-independent ${ }_{\text {ss }}$ reason when he follows the law because it is the law rather than following it because the law tells Bert to do something that is good.

In this debate, moral rules are usually understood as reasons for acting because their content has substantive moral merit. Thus, the force of moral rules qua reasons for acting derives from the substantive merit of their content. If "helping people in poverty-stricken nations" is a moral rule, its normative force derives from the merit of helping people in povertystricken nations. Moral rules cannot be content-independentss reasons for acting because their force derives from the merit of their content. Since legal rules are content-independentss reasons for acting, according to Shapiro, moral rules cannot guide conduct qua legal rule.

My view is that Shapiro cannot demonstrate the first requirement of his argument: Moral rules cannot be content-independent reasons for acting. I give three reasons. First, I show that Shapiro's exposition of Hart's treatment of content-independent reasons is wrong. Second, I argue that the normative force of legal rules qua reasons for acting is better explained by Hart's conception of content-independent reasons. Third, I show that Shapiro must be committed to Hart's conception of content-independent reasons to explain the normativity of legal rules.

Consider the following quote from Hart:

[When giving content independent reasons, ] the commander intends his expression of intention to be taken as a reason for doing them. It is therefore intended to function as a reason independently of the nature or character of the actions to be done. ${ }^{12}$

In other words,

In a case in which $\mathrm{A}$ issues a command to $\mathrm{P}$ to $\varphi, \mathrm{P}$ has a contentindependent reason to $\varphi$ only if $\mathrm{A}$ intends her expression that $\mathrm{P} \varphi$ to be a reason for $\mathrm{P}$ to $\varphi$. $^{13}$

\footnotetext{
${ }^{12}$ Hart, EB, 254-255.

${ }^{13}$ Stefan Sciaraffa is the first to offer an intention-based reading, a reading that uses the intention of another as a condition to having a content-independent reason for acting, of Hart's account of content independent reasons. In addition, Sciaraffa demonstrates the pervasiveness with which most legal theorists misread Hart's account. See
} 
On this reading of content-independent reasons (hereafter called content-independent ${ }_{\mathrm{IB}}$ reasons), suppose Big Bird tells Oscar the Grouch to wash the trashcan. Also suppose a reason why Oscar is guided by Big Bird's speech act is because Oscar takes Big Bird's intention — that Oscar washes the trashcan — for a reason to act. This kind of reason is content-independent $t_{\mathrm{IB}}$. This is to be contrasted with other reasons Oscar might have to wash the trashcan such as "dirty trashcans smell bad and attract rats." Suppose Oscar decides to wash the trashcan only for these reasons rather than taking Big Bird's intention as a reason to act. On Hart's account, Oscar was not guided by Big Bird's speech act. Moreover, content-independent ${ }_{\mathrm{IB}}$ reasons are "agentrelative" because it is in the nature of intentions that they are directed at each agent individually. ${ }^{14}$ An agent-relative value is one that figures especially in the life of the practical reasoner and is thus especially relevant to his or her practical reasoning. ${ }^{15}$

The immediate contrast between the two readings is that the normative force of contentindependentss reasons stems from the kind of reason it is. That is, things like commands, requests, promises, and legal rules have the property F-ness, and things with the property F-ness provide reasons to act simply because they have the property F-ness. In addition, they provide reasons to act that are independent of the merit of acting on them. But Shapiro has not

Stefan Sciaraffa, “On Content-Independent Reasons: It's Not in the Name," Law and Philosophy 28, (2009): 233260. I thank Christie Hartley for helping me formulate this formula of content-independent reasons. After pressure from both William Edmundson and Andrew Altman, I decided to diverge from Sciaraffa's formulation of contentindependent reasons. Sciaraffa uses intentions as both a necessary and sufficient condition to have a contentindependent reason for acting.

${ }^{14}$ Derek Parfit's definition of agent-relative reasons is "[they give] to different agents different aims." See Derek Parfit, Reasons and Persons, (Oxford, Oxford University Press, 1984), 27.

15 John Gardner and Timothy Macklem, "Reasons" in The Oxford Handbook of Jurisprudence \& Philosophy of Law edited by Jules Coleman and Scott Shapiro, (Oxford, Oxford University Press, 2002), 455. The distinction between agent-relative and agent-neutral was first introduced by Thomas Nagel, The Possibility of Altruism (Oxford:

Clarendon Press, 1970), 90-5. 
unequivocally told us what the property F-ness is. ${ }^{16}$ I explore what the property F-ness could mean to Shapiro shortly. With respect to content-indepenent ${ }_{\mathrm{IB}}$ reasons, a theorist could be silent on whether or not content-independent $\mathrm{IB}_{\mathrm{B}}$ reasons have any normative force at all because the view is merely claiming that when someone tells $\mathrm{P}$ to $\varphi$, she intends her expression to be a reason for P to $\varphi$. However, just because Sarah Palin intends people to shoot Democrats, does not mean they have a reason to shoot Democrats. One might ask what role do contentindependent $\mathrm{IB}_{\mathrm{IB}}$ reasons have if they are only putative reasons for acting. I explain their role and give reasons that show Shapiro's account is deficient.

\section{Reason 1: There is textual evidence that Hart did not hold Shapiro's conception of content- independent reasons.}

I give three expository reasons for supporting the above reading of content-independent $t_{\mathrm{IB}}$ reasons as Hart's view. First, when discussing his account of content-independent reasons, Hart does not mention anything about the content of the reason. Hart talks about the intent or intention of the authority. Moreover, when Hart describes content-independent reasons in his work, he does not always mention "content" in his explanandum, whereas he always mentions “intention." Second, Hart explicitly endorses the recognition-of-intention analysis of imperative meanings. ${ }^{17}$ Hart claims that he is following H.P. Grice, who gives an analysis of meaning much like Hart's analysis of imperatives. ${ }^{18}$ Third, Hart criticizes Bentham for not clearly explaining the

\footnotetext{
${ }^{16}$ At one point, he says, "directives are intended to be content-independent reasons for action, meaning that they are supposed to be reasons simply because they have been issued and not because they direct subjects to perform actions that are independently justifiable," Shapiro, “Authority," 389, emphasis given by me. Concerning legal rules, he says, "the fact that the rule requires the act be done is, by itself, a reason to perform that act." Between the two claims, we could say that a likely candidate for the property F-ness is that it is the property of telling people what to do. However, Shapiro also thinks requests are content-independent reasons for acting, and requests do not tell people what to do, but rather they ask people to do something.

${ }^{17}$ Hart, EB, 244, 251.

${ }^{18}$ Hart cites the very same article that I quote Scaiaraffa as explaining in footnote 2. Scaiaraffa explains, "Grice's analysis of non-natural meaning is as follows: "A meant $\mathrm{NN}_{\mathrm{N}}$ something by $\mathrm{x}$ " is (roughly) equivalent to "A intended the utterance of $x$ to produce some effect in an audience by means of the recognition of this intention," Grice,
} 
role of intention in imperatives, which Shapiro, too, fails to adequately explain. Thus, Hart asserts that an analysis of imperatives that does not mention anything about intention is defective; Shapiro's explanation of content-independent reasons is one such analysis. ${ }^{19}$ The following quote from Hart supports an intention-based reading of content-independent reasons:

Bentham was therefore right in thinking that it is part of commanding and the other imperative speech acts which characteristically make use of the imperative mood that the speaker intends his hearer in some way to recognize his wish that he should do the act. Where he went wrong was in not seeing or at any rate in not making clear ... that strictly what the commander intends his hearer to recognize is not that he, the commander, merely wishes the act to be done but more specifically that his intention in speaking is to get the hearer to do it through the latter's recognition that the commander has spoken with that intention. In other words, the commander intends his hearer to recognize the giving of a command as a step intentionally taken towards furthering the commander's intention to get his hearer to act.

When someone offers a content-independent $\mathrm{IB}_{\mathrm{B}}$ reason, she intends her expression that $\mathrm{P} \varphi$ to be a reason for $\mathrm{P}$ to $\varphi$. But one might argue that P's having a content-independent reason is not a matter of anyone intending since intention is not a necessary condition to have a reason for acting. ${ }^{20}$ For example, Ernie leaves the stove on before taking a nap and, while napping, murmurs aloud, “Turn off the stove!” Bert walks in and overhears Ernie's utterances. One might argue that Bert has a reason to turn off the stove even though Ernie did not intend for Bert to turn off the stove.

Nevertheless, it is doubtful that we should draw any theory-challenging inferences from our intuitive response to the counterexample above. It is asking whether Bert has a reason at all

"Meaning," The Philosophical Review 64 (1957): 377-388, 385. See Scaiaraffa, “On Content-Independent Reasons," 244.

${ }^{19}$ Hart thinks that content-independence is a feature of a command. Hart then asserts that the feature contentindependence could be used to illuminate aspects about legal rules. To do this, he says, "the first and most important step would be to generalize the notion of a content-independent peremptory reason for action and to free it from any necessary or specific connection with the notion of a command which would then fall into places as one particular variant of the general idea," Hart, "Commands and Authoritative Legal Reasons," 259.

${ }^{20}$ I thank Bill Edmundson for pushing me on this point. 
to turn off the stove; notwithstanding, Ernie's lack of intention that Bert turn off the stove.

However, Bert can have a reason to turn off the stove that is explained by another account of reasons. For example, Bert could have a prudential reason to turn off the stove. This explanation for why Bert should turn off the stove is compatible with the intention-based view of content-independent reasons. The view is only claiming that when someone tells $\mathrm{P}$ to $\varphi$, she intends her expression to be a reason for $\mathrm{P}$ to $\varphi$.

\section{Reason 2: Shapiro's conception of content-independent reasons cannot explain that legal} rules are normative reasons for acting without begging the question.

We have two competing conceptions of content-independent reasons: contentindependent $_{\mathrm{SS}}$ and content-independent $\mathrm{IB}_{\mathrm{B}}$. Shapiro thinks that his conception of contentindependent reasons is more consistent with the structure for which legal rules are normative reasons for acting. Again, content-independentss reasons for acting give an agent a reason to comply irrespective of whether the agent has reasons to act on its content. The normative force of content-independentss reasons is explained by the type of reason it is. For example, promises

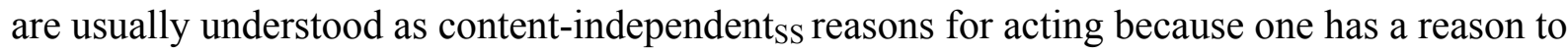
keep one's promises irrespective of the merit of the content of the promise. If Elmo promises Big Bird that he will stop lighting kittens on fire, then Elmo has a reason to keep his promise because Elmo has promised, not because refraining from lighting kittens on fire is a good thing to do. Similarly, requests are usually understood as content-independentss reasons for acting. Bert requests that Ernie check to see if Ernie has left the stove on before Ernie goes to sleep. Bert's request gives Ernie a reason to act that is independent of considerations like Ernie's forgetfulness when it comes to turning off the stove after cooking. It is the fact that Bert asked, 
rather than what Bert asked, which gives Ernie a reason to act. ${ }^{21}$ Shapiro thinks that the normative force of legal rules operates in the same manner. Agents who are committed to legal rules, according to Shapiro, "conform simply because the rule regulates the action in question,",22 and not because of what the legal rule says.

But Shapiro has not answered the following question: how should we understand the structure of normativity of legal rules? In other words, why are legal rules normative reasons for acting? Shapiro must mean legal rules are normative reasons for acting because they are instances of reason-types for an action $\varphi$ that have normative force irrespective of the action substituted in place of $\varphi .^{23}$

To be sure, Shapiro's analysis does have some phenomenological appeal. When I think about why I do not violate copyright laws, I conform merely because it is the law and not because there is any merit in conforming (perhaps violating copyright laws is convenient for reading groups and could thereby facilitate learning). But having phenomenological appeal will not help Shapiro. Equally plausible is that I conform to copyright laws because it is the intention of the members in the United States' legislature branch that I conform to copyright laws.

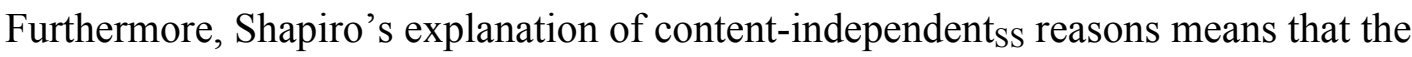
normative force of legal rules being reasons for acting is "agent-neutral" because the explanation requires all people to follow legal rules irrespective of the action the legal rule requires. ${ }^{24} \mathrm{~A}$ value is agent-neutral if there are reasons not only for A to fulfill them but also for B, C, D,

\footnotetext{
${ }^{21}$ Shapiro worded his description of requests in this manner, but I changed the names in the example. See Shapiro, "On Hart's Way Out," 175.

22 Shapiro, “On Hart's Way Out,” 175.

${ }^{23}$ I used Sciaraffa's discussion to help me formulate my thoughts here. See Sciaraffa, “On Content-Independent Reasons," 239.

${ }^{24}$ Parfit's definition of agent neutral reasons is "[they give] to all agents common ... aims." See Parfit, Reasons and Persons, 27.
} 
etcetera; it is a valuable activity that is in principle everybody's business. ${ }^{25}$ It is in principle everybody's business to follow legal rules simpliciter simply because of the type of object a legal rule is - namely, a rule that regulates his and her actions.

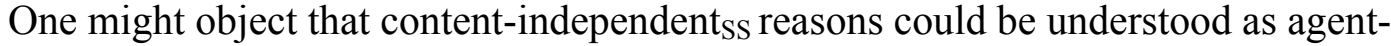
relative; however, my point is that Shapiro's argument requires content-independent ss $_{\text {reasons to }}$ be understood as agent-neutral because it is a requirement of his argument that contentindependent $_{\mathrm{SS}}$ reasons require all agents to conform to the rule irrespective of its content in order to conclude that moral rules are incapable of guiding anyone qua legal rule.

Moreover, Shapiro cannot explain the normativity of legal rules from his conceptual analysis of what legal rules are without begging the question. He must give a separate answer to explain why legal rules are normative reasons for acting. Afterwards, Shapiro can then explain that legal rules are content-independentss reasons for acting.

Analogously, philosophers must explain why agents should keep promises before they can explain which kind of reason a promise is. For example, a rule utilitarian might claim that promises should be kept because this rule if generally followed would increase overall utility more than any alternative rule regarding promise-keeping. ${ }^{26}$ This explanation supports a reading of keeping-promises as content-independentss reasons for acting because, according to rule utilitarians, instead of being utility calculators every time one faces the decision of whether to keep a promise or not, people ought to perform the action necessary to keep the promise irrespective of what the action might be. ${ }^{27}$

\footnotetext{
${ }^{25}$ John Garder and Timothy Macklem, "Reasons," 454-455 fn 20, 458

${ }^{26}$ For a rule-utilitarian defense of promissory obligations, see John Rawls, "Two Concepts of Rules," in Collected Papers ed. Samuel Freeman, (Cambridge, Harvard University Press, 1999), 20-46.

${ }^{27}$ In addition, consequentialist theories of promises are considered agent-neutral. Consider the following quote from Stephen Darwall, "Consequentialism holds an agent ought to do what will bring about the best states of affairs. The requisite value of a state of affairs is fundamentally independent of any relation to the agent - it is 'agent-neutral'.
} 
But Scanlon provides a defense of promise-keeping according to which promises ought to be kept because of the "principle of fidelity," a principle he claims no one could reasonably reject. ${ }^{28}$ Essentially, the principle of fidelity requires that the promisor keep her promise because the promisor has given the promisee the expectation and the assurance of her intention that she will fulfill the promise. Thus, the promisee has the expectation that the promisor will perform the action that keeps the promise. And, unless the promisee releases the promisor from the promise, the promisee expects the promisor to perform the action that keeps the promise. One interpretation of Scanlon's defense of promise-keeping supports a reading of promises as content-independent ${ }_{\text {IB }}$ reasons for acting because, on this reading, in any particular case, the fact that A tells $\mathrm{P}$ "I promise to $\varphi$ " means that $\mathrm{P}$ has a content-independent ${ }_{\mathrm{IB}}$ reason to act on the basis of the promise. ${ }^{29}$ If Elmo has promised Big Bird that he will stop lighting kittens on fire, and Big Bird asserts, "Elmo, do not light anymore kittens chicks on fire," then Big Bird has not released Elmo from his promise and intends his expression to be a reason for Elmo to refrain from lighting kittens on fire. In these cases, the truth of the principle of fidelity and the fact that the promisee expects the promisor to $\varphi$ are enabling conditions for the promisor to $\varphi$.

The point is that legal theorists, nearly unanimously, think that promises are contentindependentss for acting, but they think so without explaining why promises are normative

Even if the valuable state of affairs essentially includes an action, its value is independent of being the agent's action-of being his. For example, if S's keeping his promise is intrinsically valuable, it is so independently of its being his keeping of his promise," Darwall, "Agent-Centered Restrictions Inside and Out," Philosophical Studies 50, no. 3 (1986): 293.

${ }^{28}$ Scanlon's Principle F is the following: If (1) A voluntarily and intentionally leads B to expect that A will do X (unless B consents to A's not doing so); (2) A knows that B wants to be assured of this; (3) A acts with the aim of providing this assurance, and has good reason to believe that he or she has done so; (4) B knows that A has the beliefs and intentions just described; (5) A intends for B to know this, and knows that B does know it; and (6) B knows that $\mathrm{A}$ has this knowledge and intent; then, in the absence of special justification, A must do $\mathrm{X}$ unless $\mathrm{B}$ consents to X's not being done. See Thomas Scanlon, What We Owe To Each Other, (Cambridge, Harvard University Press, 1998), 304.

${ }^{29}$ I thank Christie Hartley for helping me form my words here. I do not mean to suggest that this is Scanlon's actual view only that Scanlon's view could be interpreted to support a content-independent ${ }_{\mathrm{IB}}$ reason for acting as I have explained here. 
reasons for acting. But these theorists have merely begged the question because different answers to why we should keep our promises support different readings of content-independent reasons for acting. Analogously, a theorist must explain why legal rules are normative reasons for acting to appropriately defend which conception of content-independent reasons for acting is correct. I will defend a voluntarist view to explain the structure of normativity of legal rules. Moreover, I argue that Shapiro is committed to the voluntarist view.

Reason 3: Shapiro must be committed to the voluntarist view of legal rules.

Legal rules are "illocutionary acts." ${ }^{30}$ An illocutionary act is an attempt to realize some end by the performance of a speech act. ${ }^{31}$ The Department of Transportation passed the Explosives and Combustibles Act of 1908, which requires trucks with explosives, corrosives, or combustibles to have a sign in the rear of the truck to notify other drivers that the truck is carrying something dangerous. ${ }^{32}$ Ronald Reagan implemented Executive Order 12291, which requires all administrative rules whose estimated effect on the economy is $\$ 100$ million or more to come accompanied with a full cost and benefit analysis. ${ }^{33}$ In Brown v. Board of Education, the Warren Court announced all public places must be desegregated. ${ }^{34}$ Jeremy Bentham wrote, "A rule of Law must be predicated of some assemblage of words - It never can be predicated of a bare assemblage of naked ideas. ${ }^{35}$ Even in pure common law systems, according to Jeremy

\footnotetext{
${ }^{30}$ For an argument that argues the law is a speaker, see Mark Murphy, Natural Law in Jurisprudence and Politics, (Cambridge University Press, 2006), 37-56.

${ }^{31}$ John Searle and Daniel Vanderveken, Foundations of Illocutionary Logic, (Cambridge, Cambridge University Press, 1985), 1.

${ }^{32}$ Cornelius M. Kerwin, Rulemaking: How Government Agencies Write Law and Make Policy $3^{\text {rd }}$ edition (Washington DC, CQ Press, 2003): 39.

${ }^{33}$ Kerwin, Rulemaking: How Government Agencies Write Law and Make Policy, 61.

${ }^{34}$ Brown v. Board of Education, 347 U.S. 483 (1954).

${ }^{35}$ Jeremy Bentham in A Comment on the Commentaries, quoted by Postema, Bentham and the Common Law Tradition, (Oxford, Clarendon Press, 1986), 291. I got the pointer on the Bentham quote from Waldron. See Jeremy Waldron, Law and Disagreement (Oxford, Oxford University Press), 78.
} 
Waldron, "there are authoritative renderings of the texts of judgments handed down by courts." My point in presenting these cases is to show that there are certain end-states that operative members of state — officials and citizens — desire or value, and they achieve those end-states through illocutionary acts.

All legal rules are speech acts with propositional content. However, illocutionary acts with the same propositional content can obtain distinct results with differing illocutionary force. For example, cheering that you pay your taxes on time is distinct from predicting that you will pay your taxes on time, demanding that you pay your taxes on time, and begging that you pay your taxes on time, and so on. Identifying the illocutionary point of illocutionary acts is the most fundamental way to distinguish different illocutionary forces. The illocutionary point is the goal internal to the type of illocutionary act it is. For example, Mark Murphy asserts, "the point internal to the laying down of demands is to present an act as to-be-done. ${ }^{, 37}$ Legal rules have the same type of illocutionary force as demands. Legal rules regulate actions and require acts to be done with a non-optional character for compliance. The question then becomes, what is the structure of normativity of legal rules?

According to the voluntarist view, legal rules are illocutionary acts given by legal authorities. Legal rules are reasons for acting because they come from a legislative will. The voluntarist view is meta-ethically neutral with respect to differing meta-ethical accounts because the voluntarist view claims that legal rules are only putative reasons for acting. One might follow Hobbes and Pufendorf and claim that the sovereign who has the power to sanction

\footnotetext{
${ }^{36}$ Jeremy Waldron, Law and Disagreement, 78.

${ }^{37}$ Mark Murphy, Natural Law in Jurisprudence and Politics, pg. 45. Murphy specifies that the success condition for the law to give a nondefective command is that the party demanded has decisive reasons to comply with demand. According to Murphy, "a decisive reason to $\varphi$ is for $\varphi$-ing to be a reasonable act for one to perform and not $\varphi$-ing an unreasonable act for one to perform, and so for a law to be backed by decisive reasons is for there to be decisive reasons to perform any act required by that law," Murphy, Natural Law in Jurisprudence and Politics, 1.
} 
enables legal rules to be normative reasons for acting. ${ }^{38}$ One might follow Sarah Buss, a moral realist, and claim that a person judges $\varphi$ to be a normative reason for acting only because the person "accepts practical norms that do not themselves depend on anything she finds in her motivational set." ${ }^{\prime 39}$ One might follow Hart and claim that legal rules are normative reasons for acting because one accepts the legal rule from the internal point of view. All the voluntarist view entails is that legal rules are illocutionary acts with the same illocutionary force of a demand and are given by a legal authority.

Moreover, the voluntarist view requires that all legal rules have a social source because legal authorities are the source of legal rules. One might not agree with the voluntarist view, but that does not matter: it matters that Shapiro must agree with the voluntarist view. Shapiro is an exclusive legal positivist; he holds that every legal rule must have a social source. More specifically, Shapiro holds the "Pedigree Thesis," which asserts that legal norms are legally valid in virtue of their manner of enactment. ${ }^{40}$ But their manner of enactment must be authoritative, and the manner in which legal authorities communicate is by illocutionary acts. Moreover, legal authorities are not requesting that you pay your taxes; they are demanding that you pay your taxes.

However, the voluntarist view is not neutral with respect to the different formulations of the content-independent reasons for acting. Legal authorities are not giving instances of reasontypes for an action $\varphi$ that have normative force irrespective of the action substituted in place of $\varphi$ because they are performing illocutionary acts, and they are not giving agent-neutral reasons for acting because the illocutionary acts of legal authorities are directed at each individual

\footnotetext{
${ }^{38}$ Christine Korsgaard, The Sources of Normativity, (Cambridge, Cambridge University Press, 1996), 21-27.

${ }^{39}$ Sarah Buss, "What Practical Reasoning Must Be If We Act for Our Own Reasons," Australasian Journal of Philosophy 77, no. 4 (1999): 402.

${ }^{40}$ Shapiro, "On Hart's Way Out," 158.
} 
individually. Thus, they are giving agent-relative reasons for acting. Moreover, even if Shapiro presses on and asserts that the speech acts of legal authorities have force irrespective of the action substituted in place of their speech acts, the illocutionary point of their directives "is to present an act as to-be-done. ${ }^{41}$ That is, the illocutionary force of legal authorities' speech acts is the same as demands. And, when legal authorities demand that an act is to-be-done, they intend their demand to be a reason for P to $\varphi$. Imagine that Big Bird demands that Elmo stop lighting kittens on fire, and Elmo pretends not to hear Big Bird's demands. So, Big Bird menacingly corners Elmo and shouts, "Elmo! Stop lighting kittens on fire!” Big Bird forcibly wants Elmo to hear his demand because Big Bird intends his expression to be a reason for Elmo to stop lighting kittens on fire.

Consider the following claims: (1) All legal positivists should be committed to the voluntarist view of legal rules; (2) Shapiro is committed to the voluntarist view of legal rules. If I have successfully argued that all legal positivists should be committed to the voluntarist view of legal rules, then Shapiro is wrong about his reading of content-independent reasons qua

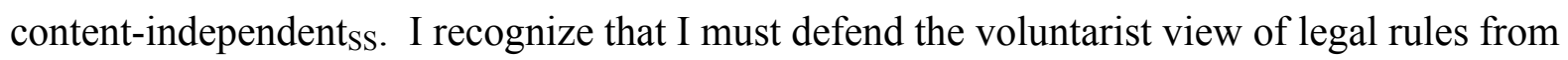
certain objections from inclusive legal positivists (and natural law lawyers), but I cannot do so in the space provided here. However, I do not need to defend this more ambitious claim because if I have successfully argued that Shapiro is committed to the voluntarist view of legal rules, then Shapiro is committed to the reading of content-independent reasons qua content-independent ${ }_{\mathrm{IB}}$. And if Shapiro is committed the reading of content-independent reasons qua contentindependent $\mathrm{I}_{\mathrm{IB}}$, and I can adequately demonstrate that moral rules can be content-independent $\mathrm{I}_{\mathrm{IB}}$ reasons for acting, then it is conceptually impossible for Shapiro to demonstrate that moral rules

\footnotetext{
${ }^{41}$ Murphy, Natural Law in Jurisprudence and Politics, 45.
} 
cannot be content-independent reasons. I contend that moral rules can be content-independent ${ }_{\mathrm{IB}}$ reasons for acting in the following respect.

In summary, with the proper understanding of content-independent reasons, moral principles can be content-independent reasons for acting. Judges can cite moral principles as contentindependent reasons $\mathrm{I}_{\mathrm{IB}}$ for acting simply because the judge intends the participants to conform to moral principles. It matters not what the actual content of the judge's command is, only that the judge intends the participants to take her ruling as a reason to act. Thus, I conclude that Shapiro fails to demonstrate the first major requirement of challenge: Moral rules cannot be contentindependent reasons for acting.

\section{Peremptory reasons for acting}

While I find fault with Shapiro's view of content-independent reasons, I assume that his exposition of "peremptory reasons" for acting is correct. ${ }^{42}$ A peremptory reason for acting is a reason to cut off or preclude all deliberation on whether to follow a rule, including deliberation on the merit of the rule. ${ }^{43}$ For example, suppose I have a rule not to eat meat. If I treat my rule as a peremptory reason for acting, then not only will I refrain from eating meat, but I also do not deliberate about eating meat when the opportunity arises. And since moral rules are putatively valid in virtue of their content, agents sometimes deliberate to determine whether the moral rule is morally appropriate. Thus, Shapiro argues that moral rules are not peremptory reasons for

\footnotetext{
${ }^{42}$ Shapiro's view of peremptory reasons is not without controversy. Matthew Kramer argues that the scope of deliberation that is cut off from peremptory reasons for acting is not universal. Suppose Big Bird tells the Cookie Monster to stop eating cookies, and Big Bird intends his command to be a peremptory reason for acting. Suppose further the Cookie Monster finds himself on a deserted island with only a jar of cookies. Kramer thinks that Big Bird's command would not preclude the Cookie Monster's deliberation to eat cookies under these conditions. Kramer claims that peremptory reasons for acting should not be understood as precluding deliberation under every circumstance. Since moral rules do not preclude deliberation under every circumstance, Kramer claims that moral rules can be peremptory reasons for acting. Kramer then argues that if moral rules can be peremptory reasons for acting, moral rules can guide conduct qua legal rule. It does not seem that there is a clear victor in this debate between Kramer and Shapiro.

${ }^{43}$ Hart, EB, 253.
} 
acting because agents sometimes must deliberate upon the moral appropriateness of the moral rule, and especially in hard cases judges must deliberate about candidate moral rules or principles.

Even if we assume that Shapiro is correct about the universal scope of peremptory reasons for acting, Shapiro's argument that legal rules are peremptory reasons for acting is misleading. If the voluntarist view of legal rules is correct, then mandatory legal rules are demands given by an authority. ${ }^{44}$ Since illocutionary acts are not themselves peremptory reasons for acting, it would be misleading to assert that legal rules are themselves peremptory reasons for acting. However, intentional agents can intend their illocutionary acts to be peremptory reasons for acting. Moreover, the illocutionary point of demands is not to preclude the independent deliberation of the agents that the demand is directed at because not all demands are meant to preclude deliberation, and not all authorities intend to preclude their agent's deliberation. The state can demand that citizens pay their taxes on April $15^{\text {th }}$ without intending to preclude their deliberation on whether to pay taxes or not. But intentional agents can intend their demands to be peremptory reasons for acting. If the features content-independent and peremptory reasons were to be combined to give an analysis of legal rules, the voluntarist view of legal rules entails the following reading: $A$ intends $\varphi$ to be a peremptory reason for acting. ${ }^{45}$

\footnotetext{
${ }^{44}$ In addition, Shapiro makes another set of costly expositional mistakes concerning Hart's treatment of the relation between content-independent and peremptory reasons for acting. Consider Hart's discussion on practical authority: "For to have such [practical] authority is to have one's expression of intention as to the actions of others accepted as peremptory content-independent reasons for action," Hart, EB, 253. Shapiro's account requires both features to be coordinate adjectives in order to contrast them singly to the "incompatible" features of moral rules, but Hart constructed the sentence with "peremptory" and "content-independent" as cumulative adjectives. For cumulative adjectives, the adjective "content-independent" modifies the noun "reasons for action," and the adjective "peremptory" modifies "content-independent reasons for action." Thus, from the manner in which Hart constructs the sentence, it should be read as the following: peremptory content-independent reasons for acting are reasons that are intended to cutoff independent deliberation by the agent.

45 This reading is supported by the manner in which Hart writes about both features throughout Hart's whole work that Shapiro and I are referring to. See Hart, EB, 243-268.
} 
With the correct understanding of the relationship between content-independent and peremptory reasons for acting, moral rules can be intended to be peremptory reasons for acting. Take, for example, Judge Earl's decision in Riggs v. Palmer: ${ }^{46}$ It is certainly the case that Judge Earl can intend his ruling that "no one should profit from his own wrong-doing" to be a peremptory reason for acting. In other words, it is certainly plausible that Judge Earl can intend that others follow his ruling without deliberating about its merit. Nothing conceptually precludes this fact even if the content of the ruling is moral. Thus, I conclude that Shapiro fails to demonstrate the second major requirement of challenge: Moral rules cannot be intended to be peremptory reasons for acting.

Shapiro might agree that I have explained how judges can intend their rulings to be peremptory reasons for acting; and thus, their rulings can epistemically guide ordinary citizens even if the content of their rulings is moral, but Shapiro could counter that I am now in a bind because my tactic is to assume that his exposition of peremptory reasons for acting is correct. Thus, even if content-independent reasons were intention-based, peremptory reasons for acting cut off all deliberation. Shapiro might then claim that when judges deliberate about the content of rules, they are neither epistemically nor motivationally guided by the moral content. Furthermore, judges must deliberate about moral rules to figure out which rule is morally appropriate in hard cases (e.g., judges must deliberate to determine whether a rule upholds a standard of justice or fairness). In summary, the objection is that even if I could explain that ordinary citizens could be epistemically guided by moral rules qua legal rule, I cannot explain that judges can be either epistemically or motivationally guided by moral rules qua legal rule.

\footnotetext{
${ }^{46} 115$ N.Y. 506 (1889).
} 
My response to this objection is to immediately give up the claim that moral rules are capable of epistemically guiding judges. ${ }^{47}$ However, remember that Shapiro's argument is that moral rules must be capable of either epistemically or motivationally guiding judges. ${ }^{48}$ Thus, I must explain how moral rules are capable of motivationally guiding judges, and a failure to do so is detrimental to my argument. But how are legal officials motivationally guided by moral principles in hard cases? A correct conception of motivational guidance is crucial to the outcome of this debate. Shapiro supplies his definition of motivational guidance twice.

Shapiro's general definition of motivational guidance: Someone is motivationally guided by a legal rule when his or her conformity is motivated by the fact that the rule regulates the conduct in question. ${ }^{49}$

\section{Shapiro's specific definition of Hart's account of motivational guidance: "[An] agent is motivationally guided by a rule when he treats it as both a content- independent and a peremptory reason for action." ${ }^{50}$}

In the context of Shapiro's discussion regarding motivational guidance, he used the general definition to explain the guidance component of motivational guidance. ${ }^{51}$ In addition, notice that Shapiro uses the word "treat" in his specific definition of motivational guidance; treat is Shapiro's key word to explain the motivational component of motivational guidance. The outcome of Shapiro's analysis is that judges cannot be motivationally guided by moral rules because "the judge will not be treating the rule as a peremptory reason for action, given that her

\footnotetext{
${ }^{47}$ I believe that Wilfred Waluchow has exhausted all arguments for the claim that moral rules can (partially) epistemically guide. See Waluchow, "Authority and the Practical Difference Thesis," 81.

${ }^{48}$ Here is a quote from Shapiro: "According to our first argument, however, we know that such rules cannot epistemically guide judges in adjudication. Inclusive rules of recognition do not tell judges which moral rules they should apply - they simply tell judges to apply moral rules. These rules cannot give epistemic guidance because judges are left to figure out for themselves what these rules are. Vis-à-vis such rules, they are like ordinary citizens. I am not sure, however, whether Hart need be concerned with this result either" (Shapiro, "On Hart's Way Out," 178).

${ }^{49}$ Shapiro, "On Hart's Way Out,” 173.

${ }^{50}$ Shapiro, "Law, Morality, and the Guidance of Conduct," 163.

${ }^{51}$ See Shapiro, "On Hart's Way Out," 173. In this discussion, Shapiro tries to give intensional meaning to the term "motivational guidance" from scratch. Both definitions play a role in Shapiro's argument.
} 
compliance is conditional on her judgment about the moral appropriateness of following the rule. ${ }^{, 52}$

But Hart uses the word "accept" instead of "treat" in two key places: his description of having practical authority and his description of "the internal point of view." ${ }^{.53}$ Moreover, claiming that someone is motivationally guided by a legal rule when his or her conformity is motivated by the fact that the rule regulates the conduct in question is deficient. The debate, after all, is centered on the question: how do legal rules enter into and make a difference to the practical reasoning of its agents? Saying that rules are intended to regulate the agent's action in question does not adequately explain how legal rules are supposed to enter into and make a difference to an agent's practical reasoning process.

Thus, my disagreement with Shapiro is on the following three questions. First, which is more appropriate to explain the motivational component in motivational guidance- to "accept" or to "treat?" Second, what is appropriate to explain the guidance component in motivational guidance? Third, what is the final outcome given an appropriate conception of motivational guidance? In the end, I conclude that merely because a judge engages in deliberation over a rule does not mean ipso facto a judge is not motivationally guided by the rule. I propose that Hart's specific conception of motivational guidance for judges would be the following: when a judge accepts a norm as a peremptory content-independent reason for acting, she is motivationally guided by that norm.

First, we should be clear on what the terms "to accept" and "to treat" mean. Given that a rule is roughly of the form " $\mathrm{X}$ ought to $\varphi$ in circumstances $\mathrm{C},{ }^{1,54}$ to accept a rule is to make a

\footnotetext{
${ }^{52}$ Shapiro, "Law, Morality, and the Guidance of Conduct," 163. Emphasis given by me.

${ }^{53}$ Hart, "The Concept of Law," 254-259. The internal point of view is the viewpoint of a participant in the system.

${ }^{54}$ Hart, The Concept of Law, 57.
} 
cognitive appraisal that "X ought to $\varphi$ in circumstances $\mathrm{C}$." And to treat something in a certain way is closer to a characterization of how an agent behaved in a specified manner towards something, or, to put it more generally, how an agent did act. Thus, I claim that to accept is closer to making a judgment, and to treat is closer to doing an action. And not to misrepresent Shapiro, the action that he is concerned with is treating a rule as a peremptory reason for action.

Now, both Shapiro and I claim that there is a conceptual connection between the will and the component that we think is more basic and phenomenologically closer to explaining motivation. I claim there is a conceptual connection between making a judgment that one ought to $\varphi$ and the will. Furthermore, I contend that the conceptual connection between making a judgment that one ought to $\varphi$ and the will is a defeasible one in order to account for akrasia. Akrasia is the state of mind in which someone acts against his or her better judgment through weakness of the will. For example, suppose Cookie Monster judges that he should not eat cookies. On the occasions that he does eat cookies, he is just being akratic, but he still believes that he has a reason not to eat cookies. The conceptual connection is represented as follows: If an agent judges that she ought to $\varphi$ in circumstances $C$, then either she is motivated to $\varphi$ in $C$ or is she is practically irrational. ${ }^{55}$

Shapiro claims there is a conceptual connection between doing an action - in particular, not deliberating - and the will. The conceptual connection can be represented as follows: If an agent does not deliberate that she ought to $\varphi$ in circumstances $C$, then she is motivated to $\varphi$ in $C$. If the agent does deliberate, then she is not treating the rule as a peremptory reason for acting.

But Shapiro cannot claim that the conceptual connection between actions and motivation is a defeasible one. Shapiro has to claim that there is a necessary connection between not

\footnotetext{
${ }^{55}$ This formulation is called the internalism requirement. Michael Smith defends a version that claims the connection between judgment and the will is a defeasible one. See Michael Smith, The Moral Problem, 61.
} 
deliberating and the will since his argument requires the following two conditional statements to hold: (1) If I deliberate, I am not being motivationally guided; (2) If I do not deliberate, then I am being motivationally guided. However, as far as motivation goes, neither conditional statement holds. I deliberate all the time about continuing graduate school in philosophy, but this does not mean that I am not motivated to go. I still do extra readings that have no direct impact on my thesis due to the chance that I might continue on. What is more, I do not deliberate about falling off my bike or tripping on my own feet, but I am not motivated to do either. In fact, it is the case that I do not want to fall or trip even though I do not deliberate when I do.

Nor does it seem that Shapiro's explanation of the guidance component of motivational guidance is correct. I quoted Shapiro's own formulation of Practical Difference Thesis in the introductory remarks of this paper: "Legal rules must in principle be capable of securing conformity by making a difference to an agent's practical reasoning." Shapiro to explain the shift in focus, when explaining guidance, to the fact that the rule regulates the action in question instead of continuing to focus on how legal rules affect the practical reasoning process of their agents. I will continue to focus on the Practical Difference Thesis and assert that guidance is central to how legal rules are intended to enter into and make a difference to the practical reasoning of its agents. And in any case, this whole debate is centered on an agent's practical reasoning. So why explain guidance in any other way? Consider my general formulation of motivational guidance: someone is motivationally guided by a rule when they accept the manner in which the legal rule is intended to be a reason for acting.

I offer the following three reasons for rejecting Shapiro's account of motivational guidance. First, both components - motivation and guidance- of Shapiro's account of

\footnotetext{
${ }^{56}$ Shapiro, "Law, Morality, and the Guidance of Conduct,"129. Emphasis given by me.
} 
motivational guidance are untenable. In contrast, my account of motivational guidance explains both components of motivational guidance better. Second, Shapiro's account has the implausible consequence that if a judge ever deliberates about a rule, then he can never be motivationally guided by that rule. However, it seems that certain things that agents were not motivationally guided by before can motivationally guide them later. Katie Holmes was adamantly opposed to Scientology at one point in her life, but after her marriage with Tom Cruise, she became an adamant supporter of Scientology. Conversely, my account does not have the implausible consequence that one can never be motivationally guided by a rule if they do not accept the rule as the kind of reason for acting that it was intended to be at some earlier time; perhaps at a later time they will accept the rule as a kind of reason for acting that it was intended to be. Thus, my account explains that changes in motivational guidance follows from a change in judgmentnamely, the agent accepts something that she once rejected before and vice versa.

I am finally ready to free Hart from Shapiro's charge of inconsistency with the appropriate conception of motivational guidance in place. It is the case that nothing conceptually precludes agents from accepting moral rules as peremptory reasons for acting from the start. For example, some people believe that kicking babies for fun is morally wrong, and they do not think one needs to deliberate in order to assess the moral appropriateness of that precept because they take the principle as a self-evident truth. Thus, they accept the moral rule as a peremptory reason for acting at the beginning. Furthermore, even assuming that Shapiro is right about his claim that judges must deliberate on every moral rule in order to assess its moral appropriateness, this assumption does not entail that they can never be motivationally guided by that rule if they deliberated about the content of the rule at some earlier time. For, once judges have settled whether a rule is sufficiently morally appropriate, they can then accept it as a peremptory reason 
for acting. Thus, a judge can deliberate now at $t_{1}$ and then later at $t_{2}$ accept the moral rule as a peremptory reason for acting because, as I have explained, a change in whether or not someone is motivationally guided by a rule follows from a change in judgment. Thus, even on the reading of peremptory reasons for acting as having an all things considered scope, nothing conceptually precludes agents from changing their judgment and accepting moral rules as peremptory reasons for acting later on and vice versa. For example, consider a Kantian type character-call him Bert - who determines that lying is wrong according to the categorical imperative. After deliberating, Bert accepts the rule as a peremptory reason for acting all things considered. Thus, when a Nazi soldier comes knocking on his door, Bert does not lie about the Jews hiding in his attic; rather, Bert tells the truth without deliberating. Thus, Bert can later accept the moral rule as a peremptory reason for acting with an all things considered scope even if he deliberated about the moral rule at an earlier time. Consequently, judges can be motivationally guided by moral rules qua legal rule even if they have deliberated about the moral appropriateness of that rule at some earlier time

\section{The Counterfactual Test}

On top of Hart's account of rule guidance, Shapiro adds that there must be success conditions for us to know whether a legal rule is even capable of guiding conduct. Thus, Shapiro supplies us with what he calls the "counterfactual test" to be his success condition for a rule qua legal rule to guide conduct. Another way that Shapiro unpacks Hart's explanation of the function of law is that "in order for [a rule] to have the function of guiding conduct there must be some action that it is supposed to bring about." ${ }^{, 57}$ Thus, according to Shapiro, we can know

\footnotetext{
${ }^{57}$ Shapiro, “On Hart's Way Out,” 188.
} 
whether a legal rule can successfully bring about an action with the counterfactual test. It is best to quote Shapiro's argument directly.

In order to evaluate whether a rule is capable of making a practical difference, we begin by considering cases where an agent conforms to a rule as a result of appealing to it in his practical reasoning. We then engage in the following thought experiment: We consider what the world would have been like had the agent not appealed to the rule in his practical reasoning. If the agent might not have conformed to the rule, then we say that the rule does make a practical difference for him, and therefore, is capable of making a practical difference. If, however, the agent would have conformed to the rule even if he had not appealed to it, then we say that the rule is not capable of making a practical difference for that agent. If the rule is not capable of making a practical difference for any agent, then we can say that the rule is not capable of making a practical difference simpliciter. ${ }^{58}$

Essentially, the counterfactual test amounts to the following: if agent $\mathrm{P}$ conforms to rule $\mathrm{R}$ regardless of whether $\mathrm{P}$ appeals to $\mathrm{R}$ in her practical reasoning, then $\mathrm{R}$ is not capable of making a practical difference for $\mathrm{P}$ because $\mathrm{P}$ would already have done $\mathrm{R}$. For example, if there was a law mandating that aluminum cans had to be recycled, but I was a strict aluminum can recycler anyway, then, according to Shapiro's counterfactual test, that law is incapable of making a practical difference for me. Shapiro then explains that if it is possible that $\mathrm{P}$ would not have conformed to R, then $\mathrm{R}$ is capable of making a practical difference. Thus, if I was a not-so disciplined aluminum can recycler (I recycled cans only on occasion or not at all), then that law is capable of making a practical difference for me.

Shapiro then argues that someone cannot be guided by the inclusive rule of recognition and be simultaneously guided by moral rules validated by it. Shapiro gives the following argument to demonstrate that claim (let M be a moral rule that is validated by an inclusive rule of recognition):

${ }^{58}$ Shapiro, "Law, Morality, and the Guidance of Conduct," 132. 
(1) If $\mathrm{P}$ is guided by an inclusive rule of recognition, then $\mathrm{P}$ will be guided by $\mathrm{M}$ only if $\mathrm{P}$ might not have conformed to $\mathrm{M}$ if $\mathrm{P}$ had not appealed to $\mathrm{M}$ as a legal rule but continued to be guided by the inclusive rule of recognition.

(2) Necessarily, if $\mathrm{P}$ is guided by an inclusive rule of recognition, then $\mathrm{P}$ conforms to $\mathrm{M}$;

(3) Therefore, if $\mathrm{P}$ is guided by an inclusive rule of recognition, then $\mathrm{P}$ will not be guided by M. $^{59}$

Premise (1) is a restatement of the success conditions of Shapiro's counterfactual test as explained above. ${ }^{60}$ And notice that Shapiro's conclusion (3) combined with the assumption that rules must be capable of making a practical difference in order to count as a legal rule entails that M cannot be a legal rule because it cannot make a practical difference. In addition, it is not clear that $\mathrm{P}$ must necessarily conform to $\mathrm{M}$ once $\mathrm{P}$ appeals to an inclusive rule of recognition merely because the inclusive rule of recognition has moral criteria and $\mathrm{M}$ is a moral rule. Thus, Shapiro gives the following sub-argument for (2).

For Shapiro, it is a necessary truth that if $\mathrm{P}$ appeals to an inclusive rule of recognition, then $\mathrm{P}$ will conform to $\mathrm{M}$. Shapiro argues that morality has a static nature and that the set of actions that morality is capable of motivating is fixed. Suppose that Elmo decides to follow the commands of his pastor who tells Elmo to do moral actions (which are those actions allowed or required in the Bible). Suppose further that Elmo consults the Bible, which dictates, "Thou shall not kill." Shapiro's argument claims that the contents of the Bible cannot further guide Elmo because once Elmo has decided to follow the commands of his pastor to do moral actions, then his pastor's command has picked out all moral actions including "Do not kill," which Elmo then necessarily conforms to. Shapiro is saying that once an action is morally right it is always morally right; furthermore, the inclusive rule of recognition will always regulate the same moral actions that moral rules validated by the inclusive rule of recognition regulate.

\footnotetext{
${ }^{59}$ Shapiro, "Law, Morality, and the Guidance of Conduct," 138.

${ }^{60}$ However, premise (1) uses two rules instead of just one (I used only one rule in my aluminum can example).
} 
The counterfactual test coupled with the above sub-argument for (2) independently stands on its own against inclusive legal positivism. For, according to Shapiro, if an alleged legal rule is ultimately incapable of passing the counterfactual test, then it simply cannot be a legal rule. Only legal rules with a social pedigree are capable of passing the counterfactual test. Let L be a legal rule validated by a rule of recognition:

It is not a necessary truth that if a judge is guided by an exclusive rule of recognition, then he will conform to $\mathrm{L}$, where $\mathrm{L}$ is some rule that has the appropriate social pedigree at some time t. For we can always suppose that $\mathrm{L}$ does not have the appropriate pedigree at $\mathrm{t}$, in which case a judge guided by the exclusive rule of recognition might not conform to . $^{61}$

Thus, Shapiro's success condition for passing the counterfactual test is: counterfactually, L might not have had been legally valid at time $t$.

Shapiro has managed to fight off all attacks against his counterfactual test and obtain agreement from Coleman that his counterfactual test stands against inclusive legal positivism. ${ }^{62}$ But Shapiro's counterfactual test is specious. Shapiro equivocates two senses in which moral rules are static in his counterfactual test.

In the first sense, moral rules are static because when someone is motivationally guided by the inclusive rule of recognition, which says to do $\varphi$, she will $\varphi$; and since she will $\varphi$, she automatically conforms to $M$ because $M$ also says to $\varphi$. But, according to Shapiro, she $\varphi s$ because of the inclusive rule of recognition and not because of $\mathrm{M}$. So she cannot be further motivationally guided by M. But I have given reasons to reject Shapiro's account of motivational guidance, which is, again, "someone is motivationally guided by a legal rule when

\footnotetext{
${ }^{61}$ Shapiro, "Law, Morality, and the Guidance of Conduct," 139.

${ }^{62}$ Coleman was much too quick to agree with Shapiro. Ironically, I found the inspiration for one of my counterarguments against Shapiro from Coleman. See Jules Coleman, "Positive and Negative Positivism," 10.
} 
his or her conformity is motivated by the fact that the rule regulates the conduct in question." 63 Thus, I deny that Shapiro's proffered explanation-"she $\varphi s$ because of the inclusive rule of recognition"- explains why she was motivationally guided by the inclusive rule of recognition. For my conception of motivational guidance, someone is motivationally guided by a rule when she accepts the rule as it was intended to be: In Hart's case, legal rules are intended to be peremptory reasons for acting. Thus, I explain, for Hart, she is motivationally guided by the inclusive rule of recognition when she accepts the inclusive rule of recognition as a peremptory reason for acting. But this does not mean that she cannot be further motivationally guided by M because she can also accept $\mathrm{M}$ as a peremptory reason for acting.

Shapiro can object that, when someone accepts the inclusive rule of recognition as a peremptory reason for acting, she will automatically accept $\mathrm{M}$ as a peremptory reason for acting. For example, both the inclusive rule of recognition and M command "Be moral." Elmo accepts the inclusive rule of recognition, which commands "Be moral," as a peremptory reason for acting, he will automatically accept $\mathrm{M}$, which commands "Be moral," as a peremptory reason for acting. However, with that explanation, it seems that legal rules validated by an exclusive rule of recognition would suffer the same fate as $\mathrm{Ms}$ if the exclusive rule of recognition commands, "Do legal actions," and L, which is a legal rule validated by an exclusive rule of recognition, commands "Do legal actions."

Shapiro would counter that legal rules validated by an exclusive rule of recognition would not suffer the same fate because L might not have been legally valid at time t. Shapiro's counterargument illuminates the second sense in which he thinks moral rules are static: moral rules validated by an inclusive rule of recognition will always be legally valid at time $t$. Thus,

\footnotetext{
${ }^{63}$ Shapiro, "On Hart's Way Out," 173.

${ }^{64}$ Coleman gave an example along these lines. See Coleman, "Incorporationism," 143.
} 
any Ms that might not have been legally valid at time $\mathrm{t}$ will pass Shapiro's counterfactual test. Consequently, my view is that even assuming that moral norms are substantively static, Shapiro cannot demonstrate the third major requirement of his challenge: Moral rules cannot be dynamic in the same manner that legal rules that pass Shapiro's counterfactual test are dynamic - that is, counterfactually, L might not have been legally valid at time $t$.

Consider an inclusive rule of recognition that sets out distinct conditions of legality for characteristically non-moral legal rules, $\mathrm{C}$, and moral principles, $\mathrm{C} 1$. This rule of recognition can be abbreviated as "C and C1.",65 For example, C could state the criterion, "Any rule with majority support in the judicial branch is a legal rule," and C1 could state the criterion, "Any rule that passes a constitutional test of fairness via the Due Process Clause is a legal rule.”

Shapiro's argument is that $\mathrm{C}$ might not counterfactually obtain at $\mathrm{t}$ with respect to $\mathrm{L}$ while the truth conditions of $\mathrm{C} 1$ will always obtain with respect to M. Shapiro claims the truth conditions of $\mathrm{C} 1$ will always obtain with respect to $\mathrm{M}$ because whether the content of a moral rule is sufficiently moral will never change. If a rule passes a constitutional test of fairness via the Due Process Clause, then it will always be legally valid. But C1 does not always have to point out content characteristics of a moral rule-e.g., features of a rule that are true only in virtue of its content—-because $\mathrm{C} 1$ can point out non-content characteristics of a moral rulefeatures of a rule that are true in virtue of social facts surrounding the rule. An example of a non-content characteristic that Coleman gives is that " $\mathrm{C} 1$ could state that a moral principle is a legal principle only if it is widely shared by members of the community." ${ }^{\circ 6}$ I give the example that $\mathrm{C} 1$ could state that a moral rule is a legal rule only if the moral rule could be feasibly

\footnotetext{
${ }^{65}$ Coleman uses this beginning presentation of the rule of recognition in this manner. See Coleman, "Positive and Negative Positivism," 10. I change the next step.

${ }^{66}$ Coleman, "Positive and Negative Positivism," 10.
} 
enforced without excessive financial cost. Moral rules about lying or prohibiting alcohol could not be practically enforced without a sufficiently large, dedicated police force. ${ }^{67}$

Here is my argument: if $\mathrm{C} 1$ could require criteria about the non-content characteristics of moral rules, then $\mathrm{C} 1$ will not always obtain with respect to $\mathrm{M}$. That is, $\mathrm{C} 1 \mathrm{might}$ not counterfactually obtain at $\mathrm{t}$ with respect to $\mathrm{M}$ because the non-content characteristics of moral rules are contingent facts. It is not necessarily true that every moral rule is cited in legislative committee reports or has the ability to be practically enforced. But if $\mathrm{C} 1$ might not counterfactually obtain at $t$ with respect to $M$, then $M$ might not have been legally valid at $t$. And if that is the case, then moral rules can be dynamic in the same manner that legal rules that pass Shapiro's counterfactual test are dynamic.

Shapiro could counter that $\mathrm{C} 1$ cannot pick out non-content characteristics of moral rules, but rather $\mathrm{C} 1$ must always pick out content characteristics of moral rules. That is, the inclusive rule of recognition could only have the kind of criterion that makes references to the rule's content, for example, whether or not the rule could pass a constitutional test of fairness. But no inclusive legal positivist has ever claimed that the rule of recognition must only pick out content characteristics of moral rules as criteria of legality. In fact, they claim the exact opposite. Coleman's position is there are no constraints on the criteria of legality. Thus, for Coleman, the manner in which moral principles are legally valid could concern facts about its non-content characteristics. And if that is the case, then I claim that versions of inclusive legal positivism such as Coleman's can pass Shapiro's counterfactual test. Moreover, for reasons that I cannot

\footnotetext{
${ }^{67}$ Moreover, the theorist who provoked this inclusive-exclusive debate, Ronald Dworkin, claims that moral principles need to be coupled with non-content characteristics. Dworkin asserts that, "unless we could find some such institutional support, we would probably fail to make out our case, and the more support we found, the more weight we could claim for the principle." ${ }^{, 67}$ Thus, an example that Dworkin gives is that C1 could state that a moral principle is a legal principle if it is cited in legislative committee reports. See Dworkin, "Model of Rules I," 40.
} 
argue for here, I have good reason to believe that versions of inclusive legal positivism other than Coleman's are, I believe, better situated than his for passing the counterfactual test.

\section{Conclusion}

Shapiro's charge of inconsistency is considered one of the major challenges to inclusive legal positivism. Shapiro's reductio against inclusive legal positivism is that moral rules validated by an inclusive rule of recognition can give neither epistemic nor motivational guidance to both judges and ordinary citizens. Thus, moral rules cannot be action guiding in the manner which legal rules are action guiding, and if being capable of making a practical difference is a necessary condition of legality, moral rules cannot be legal rules. I turned the reductio back onto Shapiro by arguing that moral rules can give neither epistemic nor motivational guidance only if the following statements are true: (i) moral rules cannot be content-independent reasons for acting, (ii) moral rules cannot be intended to be peremptory reasons for acting, and (iii) moral rules cannot be dynamic in the same manner which legal rules that pass Shapiro's counterfactual test are dynamic. I argue that since (i), (ii), and (iii) are false, moral rules can give both epistemic and motivational guidance to ordinary citizens and judges, respectively. Therefore, moral rules are capable of making a practical difference, and, most importantly, I can consistently hold the combination of ILP and the strong version of PDT. Thus, I contend that Shapiro's charge of inconsistency fails. 


\section{Works Cited}

Buss, Sarah. "What Practical Reasoning Must Be If We Act for Our Own Reasons," Australasian Journal of Philosophy 77, no. 4 (1999).

Coleman, Jules. "Negative and Positive Positivism," in Markets, Morals and the Law (Cambridge: Cambridge University Press, 1988).

. "Incorporationism, Conventionality, and the Practical Difference Thesis," in Hart's Postscripts to the Concept of Law, ed. Jules Coleman (New York: Oxford University Press, 2005), 278-279.

. "Constraints on the Criteria of Legality," Legal Theory 6 (2000).

Dancy, Jonathan. Ethics without Principle (Oxford: Oxford University Press, 2004), ch. 3.

Darwall, Stephen. “Agent-Centered Restrictions Inside and Out," Philosophical Studies 50, no. 3 (1986): 293.

. The Second-Person Standpoint: Morality Respect and Accountability (Cambridge: Harvard University Press 2006).

. “Authority and Reasons: Exclusionary and Second-Personal," Ethics 120 (2010): 266.

Derek, Parfit. Reasons and Persons, (Oxford, Oxford University Press, 1984).

Gardner, John and Timothy Macklem, "Reasons" in The Oxford Handbook of Jurisprudence \& Philosophy of Law edited by Jules Coleman and Scott Shapiro, (Oxford, Oxford University Press, 2002).

Grice, Paul. "Meaning," The Philosophical Review 64 (1957): 377-388.

Hart, H.L.A. The Concept of Law, 2nd ed. (Oxford, Clarendon Press, 1994). . Essays On Bentham (New York: Oxford University Pres, 2001).

Himma, Kenneth. "H.L.A. Hart and the Practical Difference Thesis," Legal Theory 6 (2000): 143.

Hohfled, W.N. Fundamental Legal Conceptions, as Applied in Judicial Reasoning, ed. W.W. Cook (New Haven: Yale University Press, 1919).

Kar, Robin. "Hart’s Response to Inclusive Legal Positivism," 95 Georgetown Law Review (2007).

Kerwin, Cornelius M. Rulemaking: How Government Agencies Write Law and Make Policy $3^{\text {rd }}$ edition (Washington DC, CQ Press, 2003): 39. 
Kramer, Matthew. "How Moral Principles Can Enter Into the Law," Legal Theory 6 (2000): 83108.

. "Throwing Light on the Role of Moral Principles in the Law," Legal Theory 8 (2002): 115-143.

Korsgaard, Christine. The Sources of Normativity, (Cambridge, Cambridge University Press, 1996), 21-27.

Postema, Gerald. Bentham and the Common Law Tradition, (Oxford, Clarendon Press, 1986).

Rainbolt, George. The Concept of Rights (Netherlands: Springer, 2006).

Murphy, Mark. Natural Law in Jurisprudence and Politics, (Cambridge University Press, 2006), 37-56.

Nagel, Thomas. The Possibility of Altruism (Oxford: Clarendon Press, 1970).

Rawls, John. "Two Concepts of Rules," in Collected Papers ed. Samuel Freeman, (Cambridge, Harvard University Press, 1999), 20-46.

Raz, Joseph. "Authority, Law, and Morality" in Ethics and the Public Domain, ed. Joseph Raz (New York: Oxford University Press, 1996), 210-237.

. "The Inner Logic of the Law" in Ethics in the Public Domain.

. Practical Reasons and Norms, 2nd ed. (Oxford, Oxford University Press, 2002).

. The Morality of Freedom (Oxford, Oxford University Press, 1986).

. The Authority of Law (Oxford, Oxford University Press, 1979).

Riggs v. Palmer 115 N.Y. 506, 22 N.E. 188 (1889)

Scanlon, Thomas. What We Owe To Each Other (Cambridge, Harvard University Press, 1998).

Searle, John and Daniel Vanderveken, Foundations of Illocutionary Logic, (Cambridge, Cambridge University Press, 1985).

Sciaraffa, Stefan. "On Content-Independent Reasons: It's Not in the Name," Law and Philosophy 28, (2009): 233-260.

Shapiro, Scott. "Law, Morality, and the Guidance of Conduct," Legal Theory 6 (2000):129. . "On Hart's Way Out" in Hart's Postscripts: Essays on the Postscripts to the 
Concept of Law, ed. Jules Coleman (New York: Oxford University Press, 2005), 149191.

Smith, Michael. The Moral Problem (Oxford, Blackwell Publishing, 1994).

Waldron, Jeremy. Law and Disagreement (Oxford, Oxford University Press).

Waluchow, Wilfred. Inclusive Legal Positivism (Oxford: Oxford University Press, 1994).

. "Authority and the Practical Difference Thesis," Legal Theory 6 (2000): 4581.

Williams, Bernard. "Internal and External Reasons," in Moral Luck, ed. Bernard Williams (Cambridge University Press, 1981). 